\title{
Determination of Aliphatic Primary Amines by Flow Injection Fluorometry Using Beryllium-Schiff Base Complexes
}

\author{
Izuo Aoki ${ }^{\dagger}$, Akira Takahashi and Kunihiro Watanabe \\ Faculty of Science and Technology, Science University of Tokyo, Noda, Chiba 278, Japan
}

\begin{abstract}
In an alkaline solution, aliphatic primary amines react with salicylaldehyde and beryllium(II) to form fluorescent Schiff base complexes. A flow injection fluorometry for the determination of aliphatic primary amines based on this reaction has been investigated. By using the established method, methylamine could be determined in the range of $\left(6 \times 10^{-6}-6 \times 10^{-3}\right) \mathrm{mol} \mathrm{dm}^{-3}$ within a relative standard deviation of $3 \%$. Ethylamine, 1-propylamine and 1-butylamine were determinable in the range of $\left(3 \times 10^{-5}-8 \times 10^{-3}\right) \mathrm{mol} \mathrm{dm}^{-3}$. With a flow rate of $0.4 \mathrm{~cm}^{3} \mathrm{~min}^{-1}, 30$ samples could be analyzed per hour. The proposed method was substantially inactive for secondary and tertiary amines, and was successfully applied to the determination of methylamine $(0.007-0.008 \%)$ contained in commercial dimethylamine reagents.
\end{abstract}

Keywords Flow injection fluorometry, beryllium-Schiff base complex, aliphatic primary amine, methylamine

A determination of aliphatic primary amines in the presence of secondary and tertiary amines is usually performed by using GC $^{1,2}$ or HPLC. ${ }^{3-5}$ Although FIA provides a simple, continuous and very rapid determination procedure, a selective determination of primary amines by FIA is difficult in the presence of secondary and tertiary amines.

The reactions of salicylaldehyde related compounds with primary amines to form colored Schiff bases are inactive for secondary and tertiary amines. ${ }^{6,7}$ Although these reactions are principally applicable to selective spectrophotometric determinations of primary amines, they are lacking in sensitivity because of the small absorptivities of the Schiff bases. The authors have already found that these Schiff bases can form fluorescent complexes by the reaction with beryllium(II) (Scheme 1).8,10 These complex-forming reactions take place quantitatively by mixing salicylaldehyde, beryllium(II) and primary amines in an aqueous solution at room temperature. The present study investigated the FIA of trace amounts of aliphatic primary amines

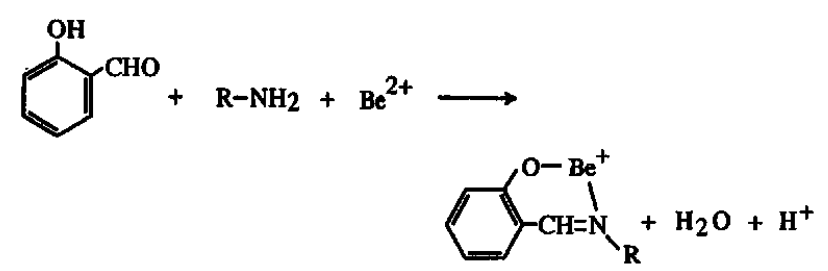

Scheme 1 Reaction among salicylaldehyde, primary amine and beryllium(II) to form fluorescent complexes.

† To whom correspondense should be addressed. using fluorescent beryllium-Schiff base complexes, which is especially useful in the presence of large amounts of secondary and tertiary amines.

\section{Experimental}

\section{Reagents}

A working solution of amines was prepared by dissolving amine hydrochlorides in distilled water. A reagent solution was prepared by mixing a $0.10 \mathrm{~mol} \mathrm{dm}^{-3}$ salicylaldehyde methanolic solution with $1.6 \times 10^{-2} \mathrm{~mol} \mathrm{dm}^{-3}$ beryllium sulfate tetrahydrate in $0.05 \mathrm{~mol} \mathrm{dm}^{-3}$ sulfuric acid and distilled water. A $0.1 \mathrm{~mol} \mathrm{dm}^{-3}$ sodium carbonate solution and a $0.2 \mathrm{~mol} \mathrm{dm}^{-3}$ triethanolamine solution were used as buffer solutions in alkaline and neutral $\mathrm{pH}$ regions, respectively. The $\mathrm{pH}$ 's of the buffer solutions were adjusted to desired values using diluted hydrochloric acid or sodium hydroxide.

\section{Flow injection procedure}

A schematic diagram of a flow injection system is shown in Fig. 1. Stainless steel tubing (i.d. $0.5 \mathrm{~mm}$ ) was used; PTFE (polytetrafluoroethylene) tubing was also available. The carrier (distilled water), the reagent solution and the buffer solution were pumped at $0.4 \mathrm{~cm}^{3} \mathrm{~min}^{-1}$ using a double-plunger pump (Nippon Seimitu Kagaku SP-D-3201). Then, $65 \mu \mathrm{dm}^{3}$ of a sample solution was injected manually into the carrier stream. Then the carrier was mixed with the reagent solution and buffer solution. After developing a fluorescent beryllium-Schiff base complex in a reaction 


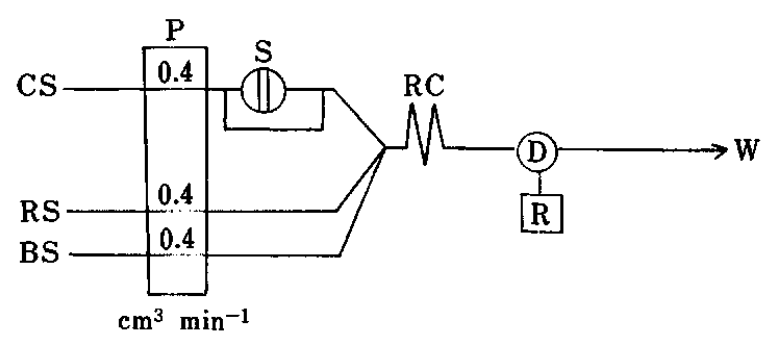

Fig. 1 Schematic diagram of flow injection system. CS, carrier solution; RS, reagent solution; BS, buffer solution; $P$, pump; S, sample injector $\left(65 \mu \mathrm{dm}^{3}\right) ; R C$, reaction coil (i.d. $0.5 \mathrm{~mm}$ ); D, detector (spectrofluorometer); R, recorder; $\mathrm{W}$, waste.

coil (10 $\mathrm{m}$ long), the fluorescence intensity was measured by a spectrofluorometer (Shimadzu RF535) equipped with a $12 \mu \mathrm{dm}^{3}$ flow-through cell. The concentrations of amines were obtained from the fluorescence peak heights on a recorder.

\section{Batchwise procedure}

To a $25 \mathrm{~cm}^{3}$ volumetric flask, a sample solution of amines, the reagent solution and the buffer solution were added. This solution was diluted to $25 \mathrm{~cm}^{3}$ with distilled water. After a Schiff base complex developed, its fluorescence intensity was measured.

\section{Results and Discussion}

The proposed method for the determination of aliphatic primary amines is based on the formation of fluorescent beryllium-Schiff base complexes. In order to confirm the basic properties of this fluorescent reaction, a preliminary investigation on reactivity with various amines was carried out according to the batchwise procedure. The results are shown in Table 1.
Methylamine showed a strong fluorescence in an alkaline region. Most of the other aliphatic primary amines examined gave a moderate fluorescence intensity in an alkaline region. The exceptional case of $t$-butylamine, which showed no fluorescence, may be ascribed to the steric effect of the bulky $t$-butyl group on the formation of the Schiff base complex. Ammonia, aromatic primary amine (aniline) and amino acid (glycine) gave almost no fluorescence, because they are too weak as bases to react with salicylaldehyde under the present experimental conditions. As can be anticipated, no fluorescence was induced by dimethylamine and trimethylamine. In the further investigations on developing the FIA system for the determination of aliphatic primary amines, methylamine was mainly used as a typical aliphatic primary amine. The fluorescence peak height in the FIA system was measured at the apparent excitation and emission maxima.

\section{Development of FIA system for methylamine}

According to the flow injection procedure, the effect of the $\mathrm{pH}$ of the buffer solution on the fluorescence peak height was investigated. As shown in Fig. 2, the maximum height was achieved at $\mathrm{pH} 12.8$. In the $\mathrm{pH}$ region below 10 , methylamine $\left(\mathrm{p} K_{\mathrm{a}}=10.6\right.$ in water at $\left.25^{\circ} \mathrm{C}\right)^{9}$ mainly exists in ammonium cation, which did not react with salicylaldehyde; in the strongly alkaline region above $\mathrm{pH} 13$, however, the decrease of the peak height with increasing $\mathrm{pH}$ could probably be ascribed to a progressive hydrolysis of beryllium(II). The effects of the concentrations of salicylaldehyde and beryllium(II) on the peak heights were indicated in Fig. 3. The maximum peak height was obtained in the ranges $(0.5-$ $1.0) \times 10^{-2} \mathrm{~mol} \mathrm{~d} \mathrm{~m}^{-3}$ of salicylaldehyde and $(0.6$ - at least 2.4) $\times 10^{-3} \mathrm{~mol} \mathrm{dm}^{-3}$ of beryllium(II). The decrease of the peak height at the salicylaldehyde concentrations above $1.0 \times 10^{-2} \mathrm{~mol} \mathrm{dm}^{-3}$ was attributed to the inner filter effects of the excess salicylaldehyde on the excitation and emission of the complex. From the results described

Table 1 Relative fluorescence intensity (RFI) of amines reacted with salicylaldehyde and beryllium(II)

\begin{tabular}{|c|c|c|c|c|c|c|}
\hline \multirow{2}{*}{ Amine } & \multirow{2}{*}{ Amine concentration $/ \mathrm{mol} \mathrm{dm}^{-3}$} & \multirow{2}{*}{$\mathrm{pH}$} & \multicolumn{2}{|c|}{ RFI } & \multicolumn{2}{|c|}{ Wavelength/nm ${ }^{a}$} \\
\hline & & & Net & Blank & Ex. & Em. \\
\hline Methylamine & $2 \times 10^{-5}$ & 11.8 & 114 & 12.2 & 330 & 430 \\
\hline Ethylamine & $2 \times 10^{-5}$ & 11.8 & 23.5 & 12.2 & 330 & 430 \\
\hline 1-Propylamine & $2 \times 10^{-5}$ & 11.8 & 18.2 & 12.2 & 330 & 430 \\
\hline 1-Butylamine & $2 \times 10^{-5}$ & 11.8 & 20.3 & 12.2 & 330 & 430 \\
\hline$t$-Butylamine & $2 \times 10^{-3}$ & $1-13$ & 0 & - & - & - \\
\hline 1-Hexylamine & $2 \times 10^{-5}$ & 11.8 & 21.0 & 12.2 & 330 & 430 \\
\hline Ethylenediamine & $2 \times 10^{-6}$ & 7.8 & 99.1 & 20.2 & 345 & 425 \\
\hline Ammonia & $2 \times 10^{-3}$ & 11.8 & 2.7 & 12.2 & 330 & 430 \\
\hline Aniline & $2 \times 10^{-5}$ & $1-13$ & 0 & - & - & - \\
\hline Glycine & $2 \times 10^{-5}$ & $1-13$ & 0 & - & - & - \\
\hline Dimethylamine & $2 \times 10^{-2}$ & $1-13$ & 0 & - & - & - \\
\hline Trimethylamine & $2 \times 10^{-2}$ & $1-13$ & 0 & - & - & - \\
\hline
\end{tabular}

Salicylaldehyde: $4.0 \times 10^{-4} \mathrm{~mol} \mathrm{dm}{ }^{-3}$; $\mathrm{Be}(\mathrm{II}): 5.0 \times 10^{-4} \mathrm{~mol} \mathrm{dm}^{-3}$; standing time: $30 \mathrm{~min}, 25^{\circ} \mathrm{C}$. a. Apparent values: the apparent excitation and emission maxima under the FIA conditions were slightly different from these values. 


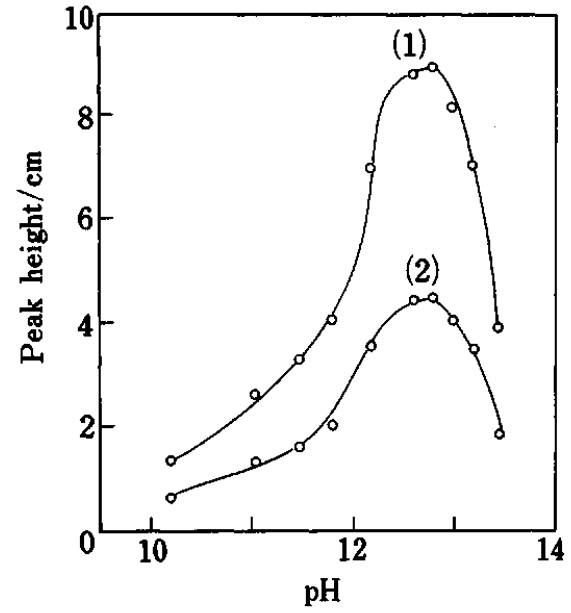

Fig. 2 Effect of pH of the buffer solution on peak height. Methylamine: (1) $1.0 \times 10^{-3} \mathrm{~mol} \mathrm{dm}^{-3}$, (2) $5.0 \times 10^{-4} \mathrm{~mol} \mathrm{dm}^{-3}$; salicylaldehyde: $5.0 \times 10^{-3} \mathrm{~mol} \mathrm{dm}^{-3} ; \mathrm{Be}(\mathrm{II}), 1.6 \times 10^{-3} \mathrm{~mol}$ $\mathrm{dm}^{-3}$; reaction coil, $1.0 \mathrm{~m}$; flow rate, $0.4 \mathrm{~cm}^{3} \mathrm{~min}^{-1}$; wavelength, $335 \mathrm{~nm} / 435 \mathrm{~nm}$.

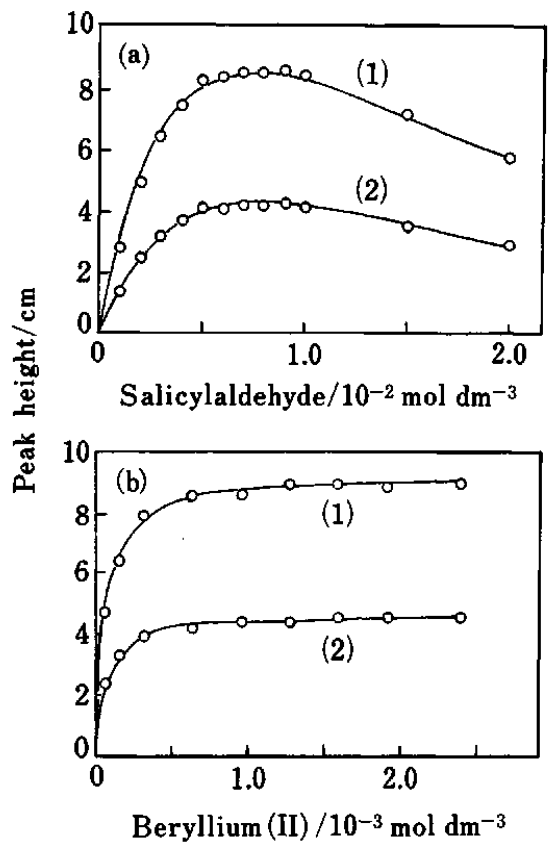

Fig. 3 Effects of concentrations of salicylaldehyde (a) and beryllium (b) on peak height. (a) and (b) methylamine: (1) $1.0 \times 10^{-3} \mathrm{~mol} \mathrm{dm}^{-3}$, (2) $5.0 \times 10^{-4} \mathrm{~mol} \mathrm{dm}^{-3} ; \mathrm{pH} 12.8$; reaction coil, $1.0 \mathrm{~m}$; flow rate, $0.4 \mathrm{~cm}^{3} \mathrm{~min}^{-1}$. (a) $\mathrm{Be}(\mathrm{II}): 1.6 \times 10^{-3}$ mol dm${ }^{-3}$, (b) salicylaldehyde: $8.0 \times 10^{-3} \mathrm{~mol} \mathrm{dm}^{-3}$.

above, the following conditions were selected for the determination of methylamine: the $\mathrm{pH}$ of the buffer solution $=12.8$, the concentrations of salicylaldehyde and beryllium(II) in the reagent solution $=8.0 \times 10^{-3}$ and $1.6 \times 10^{-3} \mathrm{~mol} \mathrm{dm}^{-3}$, respectively.

In the following investigation, the optimum reaction coil length, flow rate and sample volume were determined. The effect of the reaction coil length on the

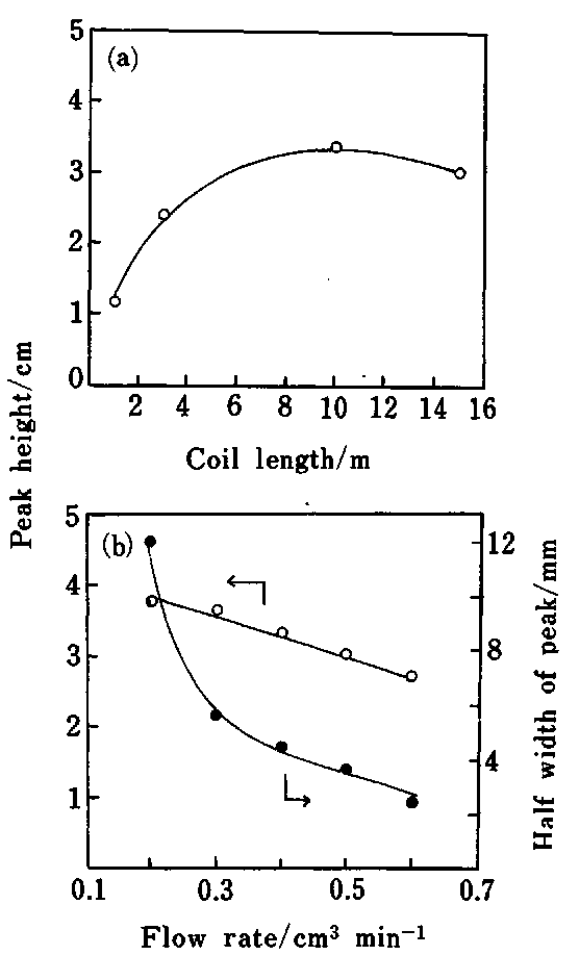

Fig. 4 Effects of reaction coil length (a) and flow rate (b) on peak height. (a) and (b) methylamine: $6.0 \times 10^{-5} \mathrm{~mol} \mathrm{dm}^{-3}$; pH 12.8; salicylaldehyde, $8.0 \times 10^{-3} \mathrm{~mol} \mathrm{dm}^{-3}$; $\mathrm{Be}(\mathrm{II}), 1.6 \times$ $10^{-3} \mathrm{~mol} \mathrm{dm}^{-3}$. (a) flow rate: $0.4 \mathrm{~cm}^{3} \mathrm{~min}^{-1}$, (b) reaction coil: $10 \mathrm{~m}$; chart speed, $60 \mathrm{~cm} \mathrm{~h}^{-1}$.

peak height was examined with the flow rate of $0.4 \mathrm{~cm}^{3} \mathrm{~min}^{-1}$. As shown in Fig. 4, the peak height increased with increasing the reaction coil length up to $10 \mathrm{~m}$. On the other hand, when the coil length of $10 \mathrm{~m}$ was used, the peak height decreased with increasing the flow rate from 0.2 to $0.6 \mathrm{~cm}^{3} \mathrm{~min}^{-1}$ (Fig. 4). Although the slower flow rate $\left(0.2 \mathrm{~cm}^{3} \mathrm{~min}^{-1}\right)$ gave better sensitivity, it broadened the fluorescence peak and served to reduce the applicable sampling rate. From the point of view of developing the rapid analysis, the flow rate of $0.4 \mathrm{~cm}^{3} \mathrm{~min}^{-1}$ was suitable in this FIA system. In the case of using the coil length of $10 \mathrm{~m}$ at the flow rate of $0.4 \mathrm{~cm}^{3} \mathrm{~min}^{-1}$, it took $110 \mathrm{~s}$ for the sample stream to reach the detector after injecting a sample solution.

To determine the suitable sample volume injected, various amounts (from $20 \mu \mathrm{dm}^{3}$ to $200 \mu \mathrm{dm}^{3}$ ) of a $6.0 \times 10^{-5} \mathrm{~mol} \mathrm{dm}^{-3}$ methylamine solution were injected, and the changes in the peak height were measured. Figure 5 shows that not only the peak height but also the peak width increased with increasing the sample volume. Taking both sensitivity and the applicable sampling rate into consideration, the sample volume of $65 \mu \mathrm{dm}^{3}$, which permitted twice as much the sampling rate as that in the case of using $200 \mu \mathrm{dm}^{3}$, was selected.

\section{Optimum FIA conditions for other primary amines}

The optimum FIA conditions for other aliphatic primary amines were also investigated. As a result of 


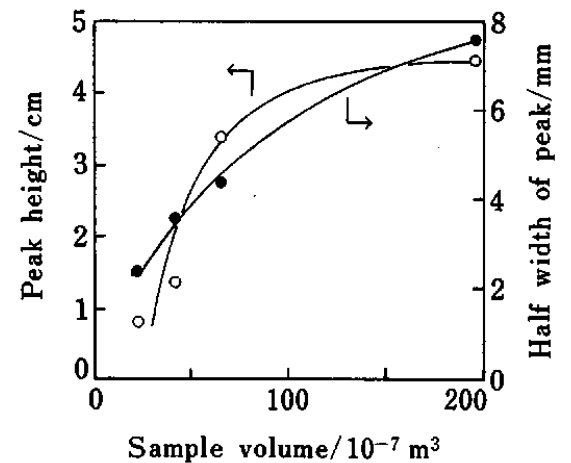

Fig. 5 Effect of sample volume on peak height. Methylamine, $6.0 \times 10^{-5} \mathrm{~mol} \mathrm{dm}{ }^{-3} ; \mathrm{pH} 12.8$; salicylaldehyde, $8.0 \times 10^{-3} \mathrm{~mol} \mathrm{dm}^{-3} ; \mathrm{Be}(\mathrm{II}), 1.6 \times 10^{-3} \mathrm{~mol} \mathrm{dm}^{-3}$; reaction coil, $10 \mathrm{~m}$; flow rate, $0.4 \mathrm{~cm}^{3} \mathrm{~min}^{-1}$; chart speed, $60 \mathrm{~cm} \mathrm{~h}^{-1}$.

research, the same conditions as those for methylamine were suitable for the determination of ethylamine, 1propylamine and 1-butylamine. In the case of ethylenediamine, the maximum fluorescence peak height was obtained at $\mathrm{pH} 7.8$, which was considerably different from the optimum $\mathrm{pH}$ value for the monoamines. This is presumably due to the difference in the $\mathrm{p} K_{\mathrm{a}}$ values of aliphatic monoamines $\left(\mathrm{p} K_{\mathrm{a}}=10.6-10.7^{9}\right)$ and ethylenediamine $\left(\mathrm{p} K_{\mathrm{at}}=6.85, \mathrm{p} K_{\mathrm{a} 2}=9.93^{9}\right)$ : in the neutral $\mathrm{pH}$ region ethylenediamine reacts with salicylaldehyde to form the Schiff base. ${ }^{10}$ The optimum concentrations of salicylaldehyde and beryllium(II) in the reagent solution were $6.0 \times 10^{-3} \mathrm{~mol} \mathrm{~d} \mathrm{~m}^{-3}$ and $1.3 \times 10^{-3} \mathrm{~mol} \mathrm{dm}^{-3}$, respectively. The suitable reaction coil length and sample volume were the same as those for methylamine.

\section{Calibration curve and accuracy}

Typical calibration graphs of methylamine and ethylamine at around the lower determination limits are shown in Fig. 6. Methylamine could be determined in the range of $\left(6 \times 10^{-6}-6 \times 10^{-3}\right) \mathrm{mol} \mathrm{dm}^{-3}$ within a relative standard deviation (r.s.d.) of 3\%. The r.s.d. $(n=10)$ for $3.0 \times 10^{-5} \mathrm{~mol} \mathrm{dm}^{-3}$ of methylamine was $0.74 \%$. Thirty samples could be analyzed per hour. Ethylamine, 1propylamine and 1-butylamine were determinable in the range of $\left(3 \times 10^{-5}-8 \times 10^{-3}\right) \mathrm{mol} \mathrm{dm}^{-3}$ within an r.s.d. of $3 \%$. Ethylenediamine could be determined in the range of $\left(5 \times 10^{-6}-1.2 \times 10^{-3}\right) \mathrm{mol} \mathrm{dm}^{-3}$.

For the determination of methylamine, co-existing 50 fold ammonia, 500-fold dimethylamine and trimethylamine caused no error.

\section{Compositions and fluorescence quantum yields $\left(\phi_{\mathrm{f}}\right)$ of beryllium-Schiff base complexes}

The $\phi_{\mathrm{f}}$ and the molar absorptivities $(\varepsilon)$ of four beryllium-Schiff base complexes in an aqueous solution (pH 11.0) were measured (Table 2). These $\phi_{\mathrm{f}}$ and $\varepsilon$ values of the four complexes were comparable with those estimated for the corresponding zinc-Schiff base $(1: 1)$ complexes ${ }^{11}$, and were almost equivalent to each other,
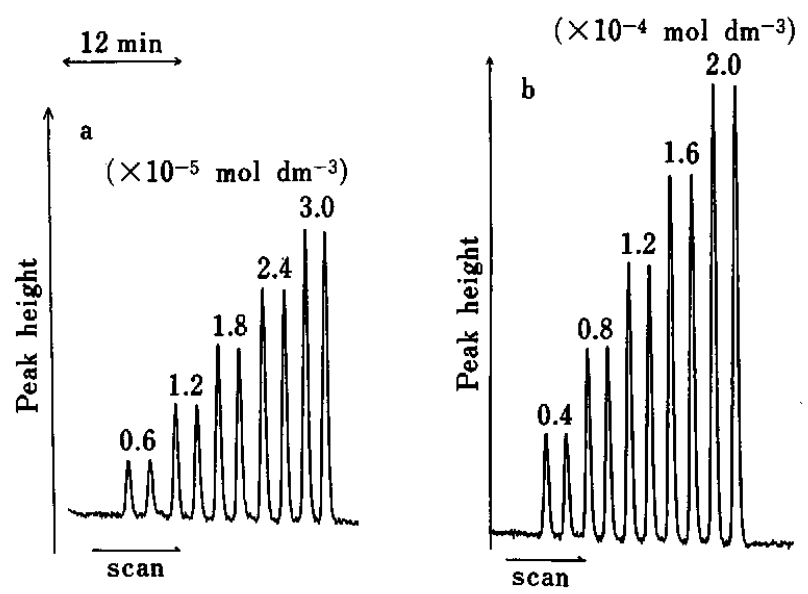

Fig. 6 Typical flow signals for methylamine (a) and ethylamine (b). (a) and (b) pH 12.8; salicylaldehyde, $8.0 \times 10^{-3} \mathrm{~mol} \mathrm{dm}^{-3} ; \mathrm{Be}(\mathrm{II}), 1.6 \times 10^{-3} \mathrm{~mol} \mathrm{dm}^{-3}$; reaction coil, $10 \mathrm{~m}$; flow rate, $0.4 \mathrm{~cm}^{3} \mathrm{~min}^{-1}$; wavelength, $335 \mathrm{~nm} / 430 \mathrm{~nm}$; chart speed, $15 \mathrm{~cm} \mathrm{~h}^{-1}$.

Table 2 Fluorescence quantum yield $\left(\phi_{f}\right)$, molar absorptivity $(\varepsilon)$ and fluorescence sensitivity index (FSI)

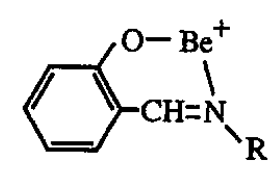

\begin{tabular}{lccc}
\hline \multicolumn{1}{c}{$\mathrm{R}$} & $\phi_{\mathrm{f}}{ }^{\mathrm{a}}$ & $\log \varepsilon_{\mathrm{abs}}(\mathrm{nm})^{\mathrm{b}}$ & FSI $^{\mathrm{c}}$ \\
\hline Methyl & 0.18 & $3.72(340)$ & 12 \\
Ethyl & 0.17 & $3.72(340)$ & 12 \\
$n$-Propyl & 0.20 & $3.71(340)$ & 14 \\
$n$-Butyl & 0.15 & $3.75(340)$ & 11 \\
\hline
\end{tabular}

a. Standard: quinine sulfate in $0.05 \mathrm{~mol} \mathrm{dm}^{-3} \mathrm{H}_{2} \mathrm{SO}_{4}\left(\phi_{\mathrm{f}}=\right.$ $0.55, \lambda_{\mathrm{ex}}=366 \mathrm{~nm}$ ).

b. $\varepsilon: \mathrm{dm}^{3} \mathrm{~mol}^{-1} \mathrm{~cm}^{-1}$.

c. $\mathrm{FSI}=\phi_{\mathrm{f}} \cdot \varepsilon / H(H$, half width of fluorescence spectrum $/ \mathrm{nm})$.

even if the amine components of the Schiff base varied from methyl to $n$-butyl. These findings suggested that the difference in sensitivity for methylamine and the other aliphatic primary amines under the determination conditions depended entirely upon the difference in the formation constants of the Schiff base complexes.

\section{Determination of methylamine in dimethylamine reagents}

The present flow injection method for the determination of aliphatic primary amines was applied to the determination of methylamine in commercial dimethylamine reagents: two kinds of dimethylamine hydrochlorides (special grade) and a 50\% dimethylamine aqueous solution. The working solutions of the samples were prepared by dissolving these reagents in distilled water, and were injected into the FIA system without further treatment. The concentration of 
Table 3 Analytical result of methylamine in dimethylamine reagents

\begin{tabular}{ccc}
\hline \multirow{2}{*}{ Sample } & \multicolumn{2}{c}{ Methylamine found, wt\% $^{\mathrm{a}}$} \\
\cline { 2 - 3 } & Calibration graph method & Standard addition method \\
\hline 1 Dimethylamine hydrochloride & 0.0076 & 0.0072 \\
(A company, special grade) & (r.s.d. $=1.40 \%, n=5)$ & 0.0073 \\
2 Dimethylamine hydrochloride & 0.0088 & \\
(B company, special grade) & (r.s.d. $=0.91 \%, n=5)$ & 0.11 \\
3 50\% Dimethylamine solution & 0.10 & \\
(C company) & (r.s.d. $=2.44 \%, n=5)$ & \\
\end{tabular}

a. Calculated as hydrochloride. In all cases methylamine could not be determined by $\mathrm{GC}$, because the signal of methylamine was hidden by that of the major component (dimethylamine). Conditions of GC: 15\% diglycerol $+5 \%$ tetraethylenepentamine $+2 \% \mathrm{KOH}$ on Chromosorb W (GLSci. Co., Ltd.); $3 \mathrm{~mm} \phi \times 3 \mathrm{~m} ; 50^{\circ} \mathrm{C}$; $1 \mathrm{~kg} \mathrm{~cm}^{-2} \mathrm{~N}_{2}+0.5 \mathrm{~kg} \mathrm{~cm}^{-2} \mathrm{H}_{2}+0.5 \mathrm{~kg} \mathrm{~cm}^{-2}$ air.

methylamine was estimated by using two different methods: the calibration method and the standard addition method. As shown in Table 3, trace amounts of methylamine $(0.007-0.008 \%$ by weight, calculated as hydrochloride), which could not be detected by GC (Table 3), could be determined with sufficient precision by the proposed FIA system.

\section{References}

1. Y. L. Sze and M. L. Borke, Anal. Chem., 35, 240 (1963).

2. Y. Hoshika, Anal. Chem., 49, 541 (1977).

3. G. M. Murray and M. J. Sepaniak, J.. Liq. Chromatogr., 6, 931 (1983).
4. S. Patrice and L. Clotilde, Anal. Chem., 59, 480 (1987).

5. I. R. C. Whiteside and P. J. Worsfold, Anal. Chim. Acta, 212, 155 (1988).

6. A. J. Milun, Anal. Chem., 29, 1502 (1957).

7. K. Yuhi, Yakugaku Zasshi, 81, 297 (1960).

8. I. Aoki, Y. Yukami and K. Watanabe, Bunseki Kagaku, 38, 674 (1989).

9. Chem. Soc. Jpn. (ed.) "Kagaku Binran, Kiso-hen II (Handbook of Chemistry, in Japanese)", p. 996, Maruzen, Tokyo, 1975.

10. K. Watanabe and I. Aoki, Bunseki Kagaku, 34, 497 (1985).

11. K. Watanabe and I. Aoki, Bunseki Kagaku, 35, 1 (1986).

(Received February 17, 1992)

(Accepted April 6, 1992) 